\title{
ANALISIS PENERAPAN ASUHAN PERSALINAN NORMAL (APN) DI RUMAH SAKIT UMUM DAERAH DOKTER SOEDARSO PONTIANAK TAHUN 2018
}

\author{
Windiyati $^{1}$
}

\author{
Akademi Kebidanan Panca Bhakti Pontianak \\ Email korespondesi: akbidpbpontianak@gmail.com
}

\begin{abstract}
Abstrak
Angka kematian ibu (AKI) dan bayi di Indonesia masih merupakan masalah kesehatan reproduksi yang sangat penting. Intervensi yang sangat kritis adalah tersedianya tenaga penolong persalinan yang terlatih. Agar tenaga penolong yang terlatih tersebut (bidan atau dokter) dapat memberikan pelayanan yang bermutu, maka diperlukan adanya standar pelayanan, karena dengan standar pelayanan para petugas kesehatan mengetahui kinerja apa yang diharapkan dari mereka, apa yang harus mereka lakukan pada setiap tingkat pelayanan serta kompetensi apa yang diperlukan. Tujuan penelitian untuk mendapatkan informasi tentang analisis penerapan pertolongan persalinan teknik APN yang yang dilakukan oleh Bidan Di RSUD Dokter Soedarso Pontianak. Penelitian ini merupakan jenis penelitian kualitatif dengan desain fenomenologi observasional dan pendekatan cross sectional. Pengumpulan data dilakukan dengan indept interview dan Focus Group Discussion (FGD). Informan dalam penelitian ini berjumlah 12 informan dan sisanya merupakan informan untuk FGD. Hasil penelitian faktor yang terkait dengan penerapan standar APN dengan sebagian besar dengan pengetahuan baik yakni $63 \%$ dan sangat sedikit yang pengetahuannya kurang yakni $16 \%$. Dan sebagian kecil masih ada dengan pengetahuan cukup yakni $21 \%$. Sikap yang meliputi perasaan sebagai seorang bidan yang bekerja di RS,didapatkan sebagain kecil yakni $32 \%$ responden mendukung dan masih terdapat sebagian kecil responden yakni 32\% kurang mendukung dan sisanya 37\% dengan kategori cukup, Motivasi semua informan dalam melakukan pekerjaan sebagai bidan rumah sakit sudah baik, tetapi motivasi informan dalam menerapkan standar APN semua masih kurang termotivasi dikarenakan APN memerlukan kesabaran. Dari variabel kepuasan kerja terdapat 9 orang (47\%) sebagian dari responden mengatakan ada inisiatif untuk bekerja sesuai dengan peran dan fungsi sebagai bidan .sisanya 10 orang responden yakni(53\%) sebagian responden yang mengatakan capek dan lelah sehingga tidak ada inisiatif lagi untuk melaksanakan selain pekerjaan pokok saja. Saran kepada Manajemen RSUD Dokter Sudarso pontianak dan untuk meningkatkan pengetahuan melalui pendidikan lanjut melalui recognisi pendidika lanjut ( RPL) ke minimal D3 Kebidanan dan pelatihan-pelatihan APN, meningkatkan keterampilan berbasis kinerja dan meningkatkan intensitas supervisi/ pengarahan yang bersifat evaluatif.
\end{abstract}

Kata Kunci: Asuhan Persalinan Normal, Pengetahuan, Bidan

\section{Pendahuluan}

Angka kematian ibu (AKI) dan bayi di Indonesia masih merupakan masalah kesehatan reproduksi yang sangat penting. Angka Kematian Ibu (AKI) masih sangat tinggi bila dibandingkan dengan negara - negara ASEAN lainnya. Sekretrariat Jenderal Kementrian Kesehatan Republik Indonesia mengatakan bahwa sudah banyak upaya kesehatan yang dilakukan untuk mencegah kematian ibu. Upaya berupa upaya promotif preventif dengan tetap memperhatikan upaya kuratif rehabilitatif. Salah satunya yaitu dengan persalinan ditolong oleh petugas kesehatan.

Data Badan Pusat Statistik 2016 menunjukkan Angka Kematian Ibu (AKI) mengalami penurunan dari sebesar 346 kematian menjadi 305 kematian ibu per 100.000 kelahiran. Menurut paparan Dirjen Kesehatan Masyarakat (2018), penyebab kematian ibu di Indonesia sebagian besar disebabkan karena perdarahan, hipertensi dan lain-lain.

\footnotetext{
${ }^{1}$ Dosen Akademi Kebidanan Panca Bhakti Pontianak
} 
Berdasarkan data profil Dinas Kesehatan Provinsi Kalimantan Barat tahun 2017, tercatat sebanyak 96 kasus kematian ibu, dengan rincian sebanyak 4 kasus kematian ibu hamil, 90 kasus kematian ibu pada saat persalinan serta sebanyak 3 kasus kematian ibu nifas. Sehingga jika dihitung, Angka Kematian Ibu (AKI) dengan jumlah kelahiran hidup sebanyak 90.117, maka Angka Kematian Ibu (AKI) di Provinsi Kal- Bar pada tahun 2017 adalah sebesar 107 per 100.000 kelahiran hidup

Data sekunder yang didapat dari bulan November 2015 sampai November 2017 dari Rumah Sakit Dr. Soedarso, terdapat 126 kasus dari 2736 persalinan $(2,17 \%)$ ibu melahirkan dengan perdarahan postpartum yang dirujuk dan $48(5,7 \%)$ diantaranya dari Desa Sei raya. Data rekam medik Rumah Sakit Dr. Soedarso menunjukkan bahwa faktor terbanyak terjadinya perdarahan postpartum adalah atonia uteri yang disebabkan pertolongan persalinan oleh non tenaga kesehatan dan penanganan komplikasi persalinan yang terlambat (54\%), jumlah anak yang banyak (22\%), ibu menderita anemia (12\%), umur terlalu muda serta umur yang terlalu tua (10\%), jarak kehamilan yang terlalu dekat $(4 \%)$ dan dari AKI itu sendiri terdapat penyebab 50\% angka kematian ibu yaitu perdarahan,eklamsi dan infeksi persalinan serta persalinan yang terlantar karena terlambat ditangani (Rekam Medik RS. Soedarso, 2017).

Intervensi yang sangat kritis adalah tersedianya tenaga penolong persalinan yang terlatih. Agar tenaga penolong yang terlatih tersebut (bidan atau dokter) dapat memberikan pelayanan yang bermutu, maka diperlukan adanya standar pelayanan, karena dengan standar pelayanan para petugas kesehatan mengetahui kinerja apa yang diharapkan dari mereka, apa yang harus mereka lakukan pada setiap tingkat pelayanan serta kompetensi apa yang diperlukan.

Adapun pelayanan kebidanan ini terdiri dari 25 standar, terbagi dalam 5 kelompok pelayanan; Standar pelayanan Umum yang terdiri dari 2 standar, Standar Pelayanan Ante Natal yang terdiri 6 standar, Standar Pelayanan Ante Natal yang terdiri dari 6 standar, Standar Pertolongan Persalinan yang terdiri dari 4 standar, Standar Pelayanan Nifas yang terdiri dari 3 standar, Standar Penanganan Kegawatan Obstetri dan Neonatal yang terdiri dari 10 standar Standar pelayanan atau asuhan kebidanan di atas merupakan pedoman bagi bidan di Indonesia dalam melaksanakan tugas, peran dan fungsinya sesuai dengan kompetensi dan kewenangan yang diberikan. Standar ini dilaksanakan oleh bidan di setiap tingkat pelayanan kesehatan baik di Rumah Sakit, Puskesmas maupun tatanan pelayanan kesehatan lain di masyarakat.

Standar Asuhan Persalinan Normal (APN) merupakan bagian dari standar pelayanan atau asuhan kebidanan. Dalam pelaksanaan standar pelayanan kebidanan bidan mengacu pada standar praktek kebidanan yang telah ada dengan menggunakan pendekatan manajeman kebidanan secara sistematis dalam menerapkan metode pemecahan masalah mulai dari pengkajian, analisa data, diagnosa kebidanan, perencanaan dan evaluasi (BKKBN, 2017). 
Bidan adalah seorang perempuan yang telah menyelesaikan Program Pendidikan Bidan, diakui oleh Negara serta memperoleh kualifikasi dan diberi izin untuk menjalankan praktek kebidanan. Bidan dalam menjalankan fungsi dan tugasnya didasarkan pada kompetensi dan kewenangan yang diberikan yang diatur melalui Peraturan Menteri Kesehatan tentang penerapan Standar APN (Permenkes, 2014).

Berdasarkan wawancara dengan kepala Diklat (pendidikan dan latihan) dan kepala ruangan bersalin Dr.sudarso Pontianak serta dari organisasi Ikatan Bidan Indonesia (IBI) sudah diterapkan dengan baik, namun tidak semua bidan dalam menolong persalinan melaksanakan langkah-langkah APN dengan benar., Dari hasil pra survey data pada bulan Januari 2018 melalui pengamatan dengan menggunakan checklist terhadap 10 orang bidan sebagai tenaga pelaksana pelayanan di RSUD Dokter Sudarso terdapat 4 orang bidan (40\%) tidak melaksanakan pelayanan persalinan dengan penerapan Standar Asuhan persalinan Normal walaupun belum secara maksimal.

Hasil wawancara terhadap 5 orang pasien menyatakan bahwa bidan tidak pernah mengkomunikasikan hal apa yang terjadi selama proses persalinan bidan dalam menolong persalinan kurang ramah, bidan kurang memperhatikan ibu yang akan melahirkan. Dari beberapa faktor pada sistem Asuhan Persalinan Normal di RSUD Dokter Sudarso Pontianak di atas sebagian belum mendukung di dalam penerapan standar Asuhan Persalinan Normal (APN).

Penerapan Standar Asuhan PersalinanNormal (APN) dikaitkan dengan pengetahuan berkaitan dengan pendidikan dimana semakin tinggi tingkat pendidikan pengetahuan akan semakin baik. Adapun pengetahuan tentang APN bagi bidan dengan latar belakang D3 Kebidanan sudah diperoleh saat mengikuti pendidikan tersebut karena didalam kurikulum D3 Kebidanan terdapat muatan tentang APN, sedangkan untuk DI Kebidanan pada saat itu belum ada muatan kurikulum tentang APN. Asuhan Persalinan Normal (APN) merupakan kebijakan pemerintah untuk semua tenaga kesehatan yang terlibat dalam pertolongan persalinan normal wajib melaksanakan Asuhan Persalinan Normal dengan memperhatikan standar yang telah ditetapkan.

Berdasarkan temuan yang ada di RSUD Dokter Sudarso Pontianak masih terdapat bidan yang belum menerapkan persalinan dengan teknik APN dengan baik, hal ini terlihat didalam melakukan pertolongan persalinan, masih ada yang tidak mengisi partograf dan terlihat sikap bidan kurang sabar dalam menangani manajemen aktif kala tiga karena ingin segera menyelesaikan persalianan dengan cepat. Dari segi Motivasi, bidan terlihat kurang perhatian dan cenderung lebih berada di ruangan bidan dan kurang memperhatikan pasien/ ibu dalam proses persalinan.

\section{Metode}

Penelitian ini merupakan jenis penelitian kualitatif dengan desain fenomenologi 
observasional dan pendekatan cross sectional. Pengumpulan data dilakukan dengan indept interview dan Focus Group Discussion (FGD). Informan dalam penelitian ini berjumlah 12 informan dan sisanya merupakan informan untuk FGD. Adapun informasi yang diteliti terdiri dari pengetahuan, sikap, motivasi, kepuasan, komunikasi, kinerja terhadap penerapan standar asuhan persalinan normal (APN) oleh Bidan.

\section{Hasil dan Pembahasan}

Berikut hasil indept interview pada informan:

\section{Pengetahuan}

Pertanyaan 1:

"Dari mana saudara ketahui tentang persalinan secara asuhan persalinan normal (APN)?".

Jawaban informan:

"-tahu tentang nolong partus teknik APN dari sosialisasi IBI dan cerita teman bidan" (R.15,17 dan 19) kotak 1.

"Saya tahu tentang pertolongan persalinan secara teknik APN dari sewaktu saya kuliah di D3 dan pernah praktekkannya"

(R.1,2,6,8,10,11,12,13,16,18) kotak 2. "Pernah lihat kepala ruangan yang nolong, hanya agak binggung gitu..." $(\mathrm{R} 3,4,7,14)$ kotak 3.

Dari hasil observasi terhadap pertologan persalinan dengan cheklis langkah APN yang dilakukan informan terlihat sebagian besar 12 orang (63\%) melakukan tekik APN dengan baik.dan sebagian kecil yakni 4 orang $(21 \%)$ dan sangatsedikit yakni 3 orang (16\%) yang kurang dalam pertologan persalinan teknik APN. Dari hasil wawancara tentang teknik pertolongan persalinan cara APN terlihat jawaban informan sebagian informan (53\%) tahu ada 58 langkah APN dan dapat melakukan teknik pertologan persalinan dengan baik dan sisanya sebagian $47 \%$ menjawab 60 langkah.

Pertanyaan 2:

"Jika saudara mengetahu teknik persalinan secara APN, tolong sebutkan ada berapa langkah dalam APN?".

Jawaban informan:

“Ada 58 langkah” (R.6,8,9,10,16,18)
kotak 4.
"Ada 60 langkah” (R..1,2,11,12,13)
kotak 5.
"Dulu 60 langkah terus berubah jadi 58
langkah ,tidak taulah mana yang benar.."
(R..7,13,14,15,17,19,) kotak 6.

Pertanyaan 3

"Apakah saudara sebagai bidan tahu tentang partogarf?".

Jawaban informan:

" Tahu sih tapi kurang paham cara isinya rumit” (R 3,4,7,9,11,12,16) kotak 7.

“...Partograf merupakan hal yang baru bagi kami, dan pemahaman kami tentang APN yang harus isi partograf masih susah dengan demikian kami belum bisa menerapkannya,....." (R 10,13,17,18,19) kotak 8.

"Partograf kan alat bantu untuk memantau kemajuan dari awal sampai akhir dan merupakan bantuan untuk membuat keputusan klinik." $(1,2,6,8,9,13)$ kotak 9.

Dari jawaban pengetahuan tentang partograf terlihat sebagian besar informan 12 orang $(63 \%)$ masih kurang dengan kategori cukup cara mengisi dan sebagian kecil 7 orang (37\%) yang cukup dapat mengisi partograf dengan benar.hal ini juga dibuktikan dengan lembaran partograf yang telah diisi bidan saat menolong partus. 


$$
\text { Menurut Maulana }
$$

Pengetahuan merupakan hasil tahu, yang terjadi setelah orang melakukan pengindraan terhadap objek tertentu. Sebagian besar pengetahuan diperoleh melalui mata dan telinga. Pengetahuan merupakan pedoman dalam membentuk tindakan seseorang (overt behavior). Hasil penelitian ini sejalan dengan penelitian yang dilakukan oleh Wattimena (2008) yang menyebutkan bahwa faktor-faktor pengetahuan, sikap, motivasi, imbalan/kompensasi, supervisi, ketidak patuhan terhadap standar dan sarana atau alat berkaitan dengan Penerapan Standar Asuhan Persalinan Normal (APN) oleh Bidan DI RSUD Kabupaten Sorong.

Hal ini juga sesuai dengan teori (Notoatmodjo, 2010) yang mengatakan bahwa salah satu faktor yang mempengaruhi pengetahuan adalah pendidikan yaitu semakin tinggi pendidikan seseorang maka semakin mudah pula mereka menerima informasi, dan pada akhirnya semakin banyak pula pengetahuan yang dimilikinya.

Salah satu faktor yang mempengaruhi pengetahuan adalah pengalaman yaitu salah satu kejadian yang pernah dialami seseorang dalam berinteraksi dengan lingkunganya. Ada kecenderungan pengalaman yang kurang baik seseorang akan berusaha untuk melupakan, namun jika pengalaman terhadap objek tersebut menyenangkan seseorang psikologis akan timbul kesan yang sangat medalam dan membekas dalam emosi kejiwaanya dan akhirnya membentuk sikap positif dalam kehidupanya.

2. Sikap Bidan dalam pelaksanaan Asuhan Persalinan Normal

Pertanyaan 1:

\section{"Apakah saudara mendukung dengan adanya pertolongan persalinan dengan teknik APN?".}

Jawaban informan:

"saya mendukung persalinan dengan
teknik APN, lebih aman dan tanpa
intervensi" (R6,8,9,10,12,16) kotak 10
"saya kurang setuju terutama kalao pasen
lagi banyak dan bidannya sibuk, kita kan
mau nya cepat karena pekerjaan kami kan
banyak" (R1,2,7,13,16,18,14) kotak 11.
"saya lebih suka nolong partus cara lama
lebih enak, tak perlu ingat-ingat langkah
dalam APN" $(1,3,4,11,17,19)$ kotak12.

Dari hasil terlihat bahwa sebagian informan mendukung dengan sikap yang baik tentang APN 6 orang (37\%), dan 7 orang (37\%) dengan sikap kurang mendukung serta 6 orangt (32\%) dengan sikap tidak mendukung.

Pertanyaan 2:

\begin{tabular}{|c|c|}
\hline $\begin{array}{l}\text { "Apakah } \\
\text { tetap }\end{array}$ & $\begin{array}{l}\text { saudara sebagai } \\
\text { menerapkan }\end{array}$ \\
\hline $\begin{array}{l}\text { persali } \\
\text { persali }\end{array}$ & $\begin{array}{l}\text { n dengan cal } \\
\text { n normal }(\mathrm{APN}) \text { ?". }\end{array}$ \\
\hline
\end{tabular}

Jawaban informan:

"Saya tergantung keadaan pasein.jika
datang dengan pembukaan sudah besar
atau lengkap, saya tidak akan nolong
dengan teknik APN".. $(R$
$6,8,10,11,12,13,16,18)$ kotak 13.
"Ya...saya akan laksanakan nolong
partus dengan APN lah, lebih aman" $(R$
$1,2,3,15,17,19)$ kotak 14.

"Saya tergantung keadaan pasein.jika datang dengan pembukaan sudah besar atau lengkap ,saya tidak akan nolong dengan teknik APN".. $\quad(R$ 6,8,10,11,12,13,16,18 )kotak 13.

"Ya...saya akan laksanakan nolong 1,2,3,15,17,19) kotak 14 . 
"saya tetap nolong partus dengan cara yang kami pelajari dulu waktu di kuliah yakni APN kan sama yang penting pasennya selamat kan?" $(R, 4,7,14$,$) kotak$ 15.

Dari hasil tentang sikap sebagai bidan dalam menerapkan teknik APN dan terlihat bahwa hampir seluruh informan yakni 16 orang (84\%) menjawab akan menolong persalinan dengan teknik APN dan sisanya hanya 3 orang yakni (16\%) yang mengatakan melihat keadaan pasein baru tentukan teknik APN.

Sikap adalah kesiap-siagaan mental, yang dipelajari dan diorganisasi melalui pengalaman, dan mempunyai pengaruh tertentu atas cara tanggap seseorang terhadap orang lain, obyek, dan situasi yang berhubungan dengannya. Sikap merupakan suatu kecenderungan yang dipelajari apa yang dihadapi dan diungkapkan dalam bentuk perbuatan, tindakan, ucapan maupun emosi seseorang.Sikap ini dipengaruhi oleh faktor usia seseorang.

Menurut Muchlas (2008) bahwa kedewasaan seseorang diketahui dari umur sebagai faktor untuk mengetahui kemampuan, pengetahuan, persepsi dan bersikap dalam bertindak, berpikir dan mengambil keputusan. Pendidikan juga mempunyai kontribusi yang besar dalam pembentukan sikap seseorang yang dapat meningkatkan pengetahuan sebagai respon kognitif, afektif dan psikomotor yang ditampilkan dengan sikap bidan dalam berperan sebagai penolong persalinan.
Sikap tersusun atas 3 (tiga) komponen yakni kognitif, afektif dan perilakunya.Sikap yang berkaitan dengan pekerjaan membuka jalan evaluasi positif atau negatif yang dipegang para karyawan mengenai aspekaspek dari lingkungan kerja mereka. Seseorang dengan tingkat kepuasan kerja tinggi menunjukkan sikap yang positif terhadap kerja itu. Seseorang yang tidak puas dengan pekerjaannya menunjukkan sikap yang negatif terhadap pekerjaan itu.

Dari hasil penelitian diketahui bahwa sikap yang mempengaruhi bidan dalam melaksanakan pertolongan persalinan teknik APN lebih banyak dibanding sikap yang tidak mempengaruhi, hal ini disebabkan sikap positif suatu tindakan yang berdasarkan pada sedikit atau banyak pengalaman mempengaruhi seseorang dalam menentukan sikap.

Temuan ini sependapat dengan Notoatmodjo (2010) yang mengatakan bahwa sikap merupakan reaksi atau respon yang masih tertutup dari seseorang terhadap suatu stimulus atau objek. Sikap menggambarkan suka atau tidak suka seseorang terhadap obyek. Sikap seringkali diperoleh dari pengalaman sendiri atau dari orang lain yang paling dekat.

Sikap membuat seseorang mendekati atau menjauhi orang lain atau obyek lain. Sikap positif terhadap nilai-nilai kesehatan tidak selalu terwujud dalam suatu tindakan nyata. Contohnya: sikap diikuti atau tidak diikuti oleh suatu tindakan berdasarkan pada banyak atau sedikitnya pengalaman 
seseorang. Sikap juga merupakan suatu bentuk dari perasaan, yaitu perasaan mendukung atau memihak (favourable) maupun perasaan tidak mendukung (unfavourable) pada suatu objek (Rahayuningsih, 2008).

\section{Motivasi}

Pertanyaan 1:

“Apa motivasi anda menjadi Bidan?”
“...saya tertarik dan senang dengan
pekerjaan sebagai seorang bidan karena
merupakan pekerjaan yang mulia ...”
$(\mathrm{R} 1,2,3,4,7,8,10,11,12,15,19)$ kotak 16.
“..panggilan jiwa ingin beramal dan
menolong sesama ...” (R-
$5,6,9,13,14,17,18$,$) kotak 17$.

\begin{abstract}
Dari hasil wawancara dengan informan didapatkan bahwa seluruh informan mempunyai motivasi yang baik dalam melaksanakan pekerjaan sebagai bidan. Hampir seluruh informan sebanyak 93,10\% memiliki motivasi yang mempengaruhi dalam bertindak yakni menerapkan tindakan persalinan dengan teknik APN. Ini dikarenakan informan mempunyai kesadaran sendiri dan informan tetap mau berusaha melaksanakan APN walaupun memerlukan waktu lebih lama dan penuh kesabaran.
\end{abstract}

Temuan ini sejalan dengan penelitian yang dilakukan oleh Adriansyah dan Susman (2016) yang menyebutkan bahwa motivasi berpengaruh secara signifikan terhadap kinerja bidan. Mathis, R.L., \& Jackson dalam Adriansyah dan Susman (2009) mengatakan bahwa motivasi merupakan dorongan seseorang dalam melakukan sesuatu. Semakin tinggi motivasi seseorang maka semakin mudah tercapainya sesuatu yang diinginkan. Sebaliknya jika motivasi yang rendah maka seseorang tidak akan melaksanakan tugas yang dibebankan padanya.

Sejalan juga dengan penelitian yang dilakukan Ma'ruf dan Siswanto (2010), dimana hasil penelitiannya menemukan bahwa motivasi dapat mempengaruhi kompetensi dari Bidan. Semakin tinggi motivasi yang dimiliki oleh bidan maka kompetensi yang diperoleh juga akan semakin tinggi.

Motivasi itu timbul tidak saja karena ada unsur didalam dirinya, tetapi juga karena adanya stimulus dari luar, seberapapun tingkat kemampuan yang dimiliki seseorang, pasti butuh motivasi. Dengan perkataan lain potensi SDM adalah sesuatu yang terbatas. Tantangan yang besar karena tiap karyawan memiliki perbedaan karakteristik dan respons pada kondisi yang berbeda. Sementara kondisi itu sendiri termasuk jenis masalah, selalu berubah-ubah sepanjang waktu. Semua itu merupakan motivasi karyawan yang efektif dan didukung oleh lingkungan manajemen yang nyaman.

Penurunan motivasi dan prestasi kerja dapat terjadi bila naiknya beban kerja tanpa diikuti dengan kepuasan kerja, artinya produktifitas meningkat tidak berefek terhadap personel, kalau demikian untuk apa rajin-rajin, rajin atau tetap pada prestasi 
sebelumnya tidak berpengaruh kepada kepuasan.

4. Kepuasan Bidan dalam melakukan pekerjaan pelaksanaan Asuhan

\section{Persalinan Normal}

Pertanyaan 1:

"Apakah anda menikmati bekerja sebagai bidan?".

Jawaban informan:

"Kurang menikmati karena kurang sejahtera dan capek, kadang harus dinas malam tinggalin anak yang masih kecil" (R7,14,16,18) kotak 18.

"Nikmatilah,karena itu sudah pilihan, apalagi kalao nolong orangnya selamat nikmat sekali"

$(1,2,3,4,5,6,7,8,9,10,11,12,13,15,17,19)$ kotak 19.

Dari hasil terlihat hampir seluruh informan yakni $84 \%$ (16 orang) menyatakan menikmati sebagai bidan.artinya informan puas bekerja sebagai bidan.

Pertanyaan 2:

"Apakah anda senang dengan tingkat tanggung jawab dalam pekerjaan anda sendiri?".

Jawaban informan:

"Ya..gimana ya bu..dibilang senang tapi berat juga tanggung jawabnya, tak adalah senangnya,ini hanya karena tugas saja"(R1,2,6,8,15) kotak 20.

Pertanyaan 3:

"Apakah gaji yang diterima sesuai dengan tuntutan pekerjaan anda sebagai bidan?".

Jawaban informan:

"Kalo menurut saya sih kurang sesuai, saya kan bekerja dengan penuh resiko tetapi imbalan maupun gaji saya sebagai pegawai negeri kan kecil. Tidak ada tambahan honor, mau gimana lagi, kurang puaslah saya, tapi pasrah saja" $(3,4,5,7,9,10,11,12,13,17)$ kotak 21.

"Yasaya sih tidak puas, tapi mau gimanalagi sekarang cari kerja susah beruntung saya masih sebagai bidan dengan status PNS" $(\mathrm{R} 1,2,6,8,14,15,16,18,19)$ kotak 22.

Dari hasil diatas dapat disimpulkan bahwa hampir seluruh informan mengatakan tidak puas, terlihat 10 informan (53\%) mengatakan kurang puas karena pekerjaan penuh resiko.dan sisanya 9 orang yakni (47\%) mengatakan tidak puas karena gaji dan imbalan tidak sesuai dengan pekerjaan yang mereka laksanakan. Namun hampir seluruh informan yakni $84 \%$ mengatakan menikmati bekerja sebagai bidan, artinya hampir seluruh informan puas sebagai bidan hanya kurang puas terutama gaji dan imbalan yang diterima.

Hal ini sesuai dengan Wexley dan Yukl menyatakan bahwa kepuasan kerja adalah cara seorang pekerja atau pegawai merasakan pekerjaannya, dan merupakan generalisasi sikap-sikap terhadap pekerjaan yang didasarkan atas aspek-aspek pekerjaannya. Dijelaskan bahwa kepuasan kerja berhubungan dengan perasaan karyawan tentang pekerjaaan dan tugasnya. Ukuran kepuasan termasuk didalamnya sikap, keluarnya karyawan, ketidakhadiran, keterlambatan dan, adanya keluhan dari karyawan. Selanjutnya Robbins (2008) berpendapat bahwa kepuasan kerja adalah,

"A general attitude toward one's 
job; the difference between the amount of rewards workers receive and the amount they believe they should receive

Kepuasan kerja adalah sikap umum seorang pegawai terhadap pekerjaannya; selisih antara banyaknya ganjaran yang diterima seorang pegawai dan banyaknya, yang mereka yakini seharusnya karyawan terima. Selanjutnya Robbins menyatakan bahwa faktor penting yang mendorong kepuasan kerja adalah (1) kerja yang secara mental menantang, (2) ganjaran yang pantas, (3) kondisi kerja yang mendukung, dan (4) Rekan kerja yang mendukung. Variabelvariabel kepuasan kerja yang langsung pengaruhnya terhadap keouasan kerja yaitu: kompensasi, pekerjaan itu sendiri, kesempatan promosi, kelompok kerja, serta kondisi kerja.

Lebih lanjut Griffin (2010) menyatakan bahwa faktor-faktor yang mempengaruhi kepuasan kerja ada lima faktor utama. Faktor yang menyebabkan kepuasan dan ketidakpuasan kerja, yaitu: gaji, kesempatan untuk promosi, jenis pekerjaan, kebijaksanaan dan prosedur organisasi, dan kondisi kerja Pakar lainnya, Robbins menyatakan bahwa faktor penting yang mendorong kepuasan kerja adalah: 1) Kerja yang secara mental menantang (mentally challenging work), hal ini dapat diartikan bahwa pekerjaan yang diberikan kepada keryawan haruslah memiliki tantangan yang proposional. Pekerjaan yang dirasa tidak menantang akan menimbulkan rasa bosan, sebaliknya pekerjaan yang tantangannya terlalu berat justru akan menimbulkan rasa frustasi dan gagal

Dari pendapat tersebut, dapat dijelaskan bahwa kepuasan kerja adalah sikap umum seseorang terhadap pekerjaannya yang merupakan penilaian atau cerminan dari perasaan mereka terhadap pekerjaannya dan segala sesuatu yang dialami dalam lingkungan kerjanya. Griffin mengatakan bahwa Kepuasan kerja yaitu suatu sikap efektif dan merupakan reaksi yang evaluatif individu terhadap pekerjaannya. Sedangkan Luthans menyatakan bahwa,

"Job satisfaction as a pleasure or positive emotional state resulting form the appraisal of one job or job experience"

Kepuasan kerja merupakan suatu pernyataan emosional yang positif atau menyenangkan yang dihasilkan dari penilaian terhadap suatu pekerjaan atau pengalaman kerja.Pakar lainnya yang mengemukakan tentang kepuasan. Gibson (2009), pandangannya adalah:

"Job satisfaction is an attitude that individuals have about their job. It results from their perception of their job, based on factors of the work environment, such as the supervisor's style, policies and procedures, work group affiliation, working condition, and fringe benefif'. 
5. Komunikasi Bidan dalam Penerapan APN

Pertanyaan 1:

“Apakah saudara sebagai bidan selalu melakukan komunikasi yang baik dengan pasen saat persalinan?".

Jawaban informan:

"Komunikasi..tergantung keadaan pasein juga sih,kalau komunikasi nya enak biasanya paseinnya mau mengikuti anjuran" (R...3,4,14,19) kotak 23.

"Saya rasa terkadang pasennya tidak mau bicara selama beberapa waktu karena cemas atau marah, maka saya lebih baik diam saja” (R 7,15) kotak 24.

"Saya rasa komunikasi itu perlu karena kadang Pasen berteriak dan menangis dalam proses persainan dan saya berusaha menenangkan dengan komunikasi yang baik." $(17,18,19)$ kotak 25.

"Sering juga pasen menolak diajak ngomong.sebagai bidan saya berusaha untuk mengajak pasen komunikasi karena itu sangat penting supaya proses persalinan berjalan normal" $(1,6,8,11)$ kotak 26.

"Saya pikir Jika bidan tidak dapat berkomunikasi dengan baik pada pasen dan tidak dapat menenangkan pasen .maka bidan tidak menciptakan hubungan yang baik, nolong partus cara Apn tuh harus sabar. "(2,10,12,13,16) kotak 27.

Dari hasil wawancara terlihat bahwa sebagian besar informan yakni 14 orang (74\%) mengatakan sulit untuk berkomunikasi dengan pasen saat proses persalinan apalagi dengan teknik APN yang memerlukan kesabaran dari langkah ke langkah, sisanya hanya sebagian kecil yakni 5 orang (26\%) yang mengatakan dapat berkomunikasi dengan baik dan sabar.
Komunikasi adalah proses interaksi secara sadar yang dilakukan oleh bidan dengan klien untuk beradaptasi terhadap masalah yang dialami klien, baik gangguan secara fisik maupun psikologi, sehingga bisa membantu klien untuk mencapai kesembuhan atau mengatasi masalahnya. Tujuannya agar pasien terbantu proses penyembuhanya.

Departemen Kesehatan RI (2006) menyatakan bahwa bidan mempunyai tugas yang sangat penting dalam memberikan konseling kepada wanita sepanjang daur reproduksi dari bayi sampai nifas, KB dan genetik untuk meningkatkan kesejahteraan klien. Prinsip komunikasi pada ibu hamil: Pesan yang diberikan harus disesuaikan dengan kondisi dan umur kehamilan, ciptakan kenyamanan dan keakraban saat konseling berlangsung, konseling yang dilakukan tidak menimbulkan stres pada konseli.Konseling pada ibu bersalin mempunyai tujuan untuk kesejahteraan ibu dan agar proses melahirkan dapat berjalan dengan semestinya.

Menurut Murphy, dikutip Wursanto (2011), "Communication is the whole process used in reaching other minds", Artinya adalah Komunikasi adalah seluruh proses yang diperlukan untuk mencapai pikiran-pikiran yang dimaksud oleh orang lain.

\section{Kinerja Bidan dalam Penerapan APN}

Pertanyaan 1:

"Dengan adanya standar APN ini, apakah pekerjaan yang dibebankan sebagai tugas 
dan kewajiban sebagai bidan dapat diselesaikan tepat waktu?".

Jawaban informan:

"Tidak bisalah ,mana banyak lagi yang harus diselesaikan seperti harus mengisi format partograf" (R 7,14,17,18,19) kotak 28.

"Kadang -kadang saya tidak isi partograf karena terlalu banyak dan tidak bisa tepat waktu lah" $(3,4,15,2,6,8,11,12,16)$ kotak 29.

"Tak bisa tepat waktu,biasanya minta tolong teman yang penggantian shif yang selesaikan" (R1,2,9,10,13) kotak 30 .

Dari jawaban responden tentang tugas dan kewajiban sebagai bidan yang berkaitan dengan kinerja yang tepat waktu terlihat hampir seluruh responden menjawab tidak dapat menyelesaikan tepat waktu,14 orang (74 $\%$ ) dan sisanya 5 orang ( $26 \%$ ) yang mengatakan hanya kadang-kadang dapat menyelesaikan tugas dengan tepat waktu.

Pertanyaan 2:

"Apakah saudara dapat melaksanakan pertolongan persalinan teknik APN sesuai dengan SOP atau langkah-langkah APN?".

Jawaban informan:

"Tak bisa tepat ,kadang -kadang tidak
berurutan" (R $3,7,15,19)$ kotak 31.
"Bagaimana mau berurutan sesuai
SOP...sulit karena pasein disini kan
banyak,yang penting pasen selamat itu
saja” $(4,14,17,19)$ kotak 32.
"Kalao saya bisa sih sesuai sop kalao
pasein tak banyak .kami kan dinas Cuma
sedikit” (1,6,9,11) kotak 33.
"Saya lihat mahasiswa bisa berurutan
karena mereka hafal tapi lama
kerjanya,tak efisien,tapi saya bisa dan
hafal kok" $(2,8,10,12,13,16,18)$ kotak 34.

Dari hasil diatas terlihat 11 orang (58\%) menjawab dapat melaksanakan SOP langkah APN dan sisanya 8 orang yakni (42\%) yag tidak dapat mengerjakan teknik APN sesuai SOP.

Pertanyaan 3:

\section{"Apakah ada inisiatif sebagai bidan dalam melaksanakan tugas sesuai peran dan fungsi sebagai bidan?".}

Jawban informan:

"Ada sih inisiatif untuk bekerja sesuai
tugas dan fungs bidan” (R,7,14,15,16,18)
kotak 35 .
"Malas terkadang saya capek yang
penting saya kerja sesuai tugas sudah
cukup, karena saya pikir itu sudah
merupakan tugas kalau saya nolong pasen
melahirkan" (3,4,1,2,6,8,9,10) kotak 36.
"Melakukan bimbingan pada mahasiswa
dan bidan yang muda serta memberikan
asuhan kebidanan sesuai standar ,saya
pikir itu sudah merupakan tugas dan
fungsi saya sebagai bidan" $(11,12,13,19)$
kotak 37.

Dari hasil terlihat ada 9 orang (47\%) sebagian dari responden mengatakan ada inisiatif untuk bekerja sesuai dengan peran dan fungsi sebagai bidan .sisanya 10 orang responden yakni (53\%) sebagian responden yang mengatakan capek dan lelah sehingga tidak ada inisiatif lagi untuk melaksanakan selain pekerjaan pokok saja.

Gibson, Ivancevich dan Donnelly (2008) menyatakan bahwa kinerja adalah tingkat keberhasilan dalam melaksanakan tugas dan kemampuan untuk mencapai tujuan yang telah ditetapkan. Kinerja merujuk pada tingkat pencapaian bidan atau manajeriel terhadap persyaratan pekerjaan. Stoner (2010) mengemukakan kinerja 
sebagai prestasi yang dapat ditunjukkan oleh karyawan atau dengan kata lain merupakan hasil yang dicapai dalam melaksanakan tugas-tugas yang dibebankan kepadanya.

Salah satu kaitan dengan kinerja adalah kepuasan kerja karena merupakan faktor penentu bagi sikap perawat terhadap pekerjaannya. Kepuasan kerja merupakan rasa senang atau tidak senang perawat terhadap pekerjaannya yang beragam sehingga memberikan respon terhadap situasi kerjanya. bidan yang merasa terpuaskan terhadap pekerjaan biasanya bekerja lebih keras dan lebih baik, dibandingkan bidan yang tidak terpuaskan terhadap pekerjaannya maka akan cenderung menurun kinerjanya. Yang berarti kepuasan kerja berpengaruh positif terhadap kinerja, jika kepuasan kerja meningkat akan berakibat kinerja bidan juga meningkat.

Kondisi ini akan memungkinkan jika bidan diberi kesempatan dan tanggung jawab untuk meningkatkan keterampilan dalam memberikan pelayanan kesehatan seperti pelatihan Asuhan Persalinan Normal, sehingga dalam bekerja melaksanakan Asuhan kebidanan yang terlatih dan terampil secara mandiri. Agar bidan memperoleh kepuasan kerja RSUD Dokter Soedarso perlu memperbaiki unsur yang menjadi kepuasan kerja disamping pengetahuan, pendidikan, sikap, motivasi, dan komunikasi untuk mengembangkan diri bidan itu sendiri, dengan demikian akan terpenuhi kepuasan kerja dan peningkatan kinerja bidan akan terwujud.

Hasil penelitian ini sesuai dengan hasil penelitian yang dilakukan oleh Ostroff (2012) mengemukakan bahwa kepuasan kerja mempunyai hubungan yang signifikan dengan kinerja, selanjutnya karyawan yang merasa terpuaskan dengan baik terhadap pekerjaan biasanya bekerja lebih keras dan lebih baik dibandingkan karyawan yang mengalami stress dan tidak terpuaskan terhadap pekerjaannya. Yang berarti kepuasan kerja berpengaruh positif terhadap kinerja, jika kepuasan kerja meningkat maka kinerja bidan akan meningkat.

Robbins menyatakan bahwa faktor penting yang mendorong kepuasan kerja adalah (1) kerja yang secara mental menantang, (2) ganjaran yang pantas, (3) kondisi kerja yang mendukung, dan (4) rekan kerja yang mendukung. Salah satu aspek yang mempengaruhi kualitas pelayanan yang diberikan adalah kepuasan kerja, artinya dengan tingkat kepuasan kerja yang tinggi biasanya bidan akan memberikan pelayanan yang baik dan begitu juga sebaliknya ketika bidan tidak mengalami kepuasan kerja maka pelayanan yang diberikan kepada pasien sebagai konsumen akan rendah, kepuasan kerja bidan dirasakan penting dan perlu diperhatikan oleh manajerial, karena manusia merupakan faktor dan pemeran utama dalam proses bekerja.

\section{Kesimpulan}

Berdasarkan hasil penelitian yang diperoleh maka dapat disimpulkan bahwa 
penerapan Asuhan Persalinan Normal dipengaruhi oleh banyak faktor, diantaranya yaitu pengetahuan, sikap, motivasi, kepuasan, komunikasi dan kinerja. Saran kepada Manajemen RSUD Dokter Sudarso pontianak dan untuk meningkatkan pengetahuan melalui pendidikan lanjut melalui recognisi pendidika lanjut ( RPL) ke minimal D3 Kebidanan dan pelatihan-pelatihan APN, meningkatkan keterampilan berbasis kinerja dan meningkatkan intensitas supervisi/ pengarahan yang bersifat evaluatif.

\section{Daftar Pustaka}

Adriansyah, Agus Aan dan Susman Sjarif. 2016. Pengaruh Motivasi Terhadap Kinerja Bidan dalam Pencapaian Cakupan Persalinan di Puskesmas Kabupaten Konawe Selatan Provinsi Sulawesi Tenggara. Jurnal IKESMA Vol. 12 No. 2 September 2016

Badan Pusat Statistik. 2016. Survei Penduduk Antar Sensus (SUPAS) 2015. Direktorat Diseminasi Statistik

BKKBN. 2017. Survei Demografi dan Kesehatan Indonesia 2017. Jakarta: Kementrian Kesehatan

Cheri Ostroff. 20012. The Relatinonship Between Satisfaction, Attitudes and Performance, dan Organizational Level Analysis". Journal of Applied Psychology. Vol 77. No. 6. p. 963-974.

Depkes RI. 2006. Panduan Nasional Keselamatan Pasien Rumah Sakit (Patient Safety) Utamakan Keselamatan Pasien. Jakarta: Departemen Kesehatan Republik Indonesia

Dirjen Kesehatan Masyarakat. 2017. Peran Rumah Sakit dalam Menurunkan AKI dan AKB. Jakarta: KemenKes RI
Gibson, et al. 2009. Organizational: Behavior, Structure, Processes. New York: The McGraw Hill Companies, Inc

Griffin, Jill. 2010. Customer Loyalty, Menumbuhkan dan Mempertahankan Kesetiaan Pelanggan. Alih Bahasa Dwi Kartini Yahya. Jakarta: Erlangga

Kemenkes. 2012. Ibu Selamat Anak Sehat Fokus Hari Kesehatan Nasional Ke-48. Tersedia Pada www.kemkes.go.id Diakses Tanggal 11 Desember 2017

Ma'ruf, Nirmala Ahmad Dan Siswanto. 2010. Pengaruh Motivasi Terhadap Peningkatan Kompetensi Bidan Desa di Kabupaten Malang. Buletin Penelitian Sistem Kesehatan - Vol. 13 No. 1 Januari 2010: 77-82

Maulana, Heri. 2009. Promosi Kesehatan. Jakarta: Penerbit Buku Kedokteran EGC

Muchlas. 2008. Perilaku Organisasi. Yogyakarta: Gadjah Mada University Press

Notoatmodjo S. 2010. Ilmu Perilaku Kesehatan. Jakarta: PT Rineka Cipta

Permenkes. 2014. Peraturan Menteri Kesehatan No. 97 Tahun 2014 Tentang Pelayanan Kesehatan Masa Sebelum Hamil, Masa Hamil, Persalinan, dan Masa Sesudah Melahirkan, Penyelenggaraan Pelayanan Kontrasepsi, serta Pelayanan Kesehatan Seksual. Jakarta: Kemenkes

Profil Dinas Kesehatan. 2017. Profil Dinas Kesehatan Pontianak. Pontianak: Dinas Kesehatan Provinsi Kalimantan Barat

Rahayuningsih, S.U. 2008. Psikologi Umum 2. Jakarta: Gunadarma

Rekam Medik. 2017. Rekam Medik RS. Dr. Soedarso. Pontianak: RS. Dr. Soedarso

Robbins, P. Stephen. 2008. Organizational Behaviour, Tenth Edition (Perilaku Organisasi Ke Sepuluh), alih bahasa Drs. Benyamin Molan. Salemba Empat: Jakarta. 
Stoner, James A. F., and R. Edward Freeman. 2010. Principles of Management. New Delhi: Phi Beta Kappa

Wattimena, Maria. 2008. Thesis: Analisis Penerapan Standar Asuhan Persalinan Normal (APN) oleh Bidan di Rumah Sakit Umum Daerah Kabupaten Sorong Papua Barat Tahun 2008 (Studi Kualitatif). Semarang: Universitas Diponegoro

Wexley KN, \& Yukl GA. (2005). Perilaku organisasi dan psikologi personalia, Jakarta: Bina Aksara

Wursanto. 2011. Dasar-Dasar Manajemen Personalia. Jakarta: Dian Pustaka 